\title{
Embryotoxic and proteotoxic effects of water and sediment from the Neckar River (Southern Germany) to zebrafish (Danio rerio) embryos
}

\author{
Krisztina Vincze*, Katharina Graf, Volker Scheil, Heinz-R Köhler and Rita Triebskorn
}

\begin{abstract}
Background: The Neckar River (Southern Germany) represents an aquatic system strongly affected by numerous anthropogenic activities. Thus, it is an excellent model for ecotoxicological investigations. The present study aims to assess time and spatial variations of embryo- and proteotoxic effects in surface water and sediment. For this end, embryos of zebrafish (Danio rerio) were exposed to Neckar River samples collected in the Tübingen region in different seasons over 2 years. Additionally, quantification of the heat shock (stress) protein Hsp70 was carried out in newly hatched larvae; furthermore, physico-chemical water parameters were measured in order to gain baseline information about the limnologic conditions.

Results: Nearly all of the investigated Neckar River sites caused elevated mortality, developmental retardation and failures, modified heart rate and reduced hatching success in zebrafish embryos and larvae. Additionally, exposure to Neckar River water and sediment led to changes in larval Hsp70 level. During the 2 years of investigation, seasonal differences of embryo- and proteotoxic effects occurred. Along these lines, physico-chemical measurements delivered basic information for the interpretation of in vivo test data.

Conclusions: Our study suggests a changing toxic burden in the whole investigated study area. Consequently, for ecotoxicological field studies, time and spatial variations on small scale must be dealt with. The lethal and sublethal endpoints of the fish embryo test combined with Hsp70 level measurements proved to be effective tools for toxicity assessment of environmental samples.
\end{abstract}

Keywords: Fish embryo test; Hsp70; Biomarker; Time and spatial variations

\section{Background}

Anthropogenic chemicals entering freshwater via sewage effluents and other sources may pose a potential threat to aquatic ecosystems; therefore, environmental monitoring is a key issue in order to draw unbiased conclusions about the toxic effects on living organisms. Since it is hard to predict how organisms of different systematic levels may react to the presence of multiple pollutants, there is an obvious need for investigating their physiological responses to certain exposure situations. In this context, biological effect studies including biomarkers provide a way to carry out an overall health assessment at various organization levels $[1,2]$. Biomarkers are defined as biological responses of organisms that give a

\footnotetext{
* Correspondence: krisztina.vincze@student.uni-tuebingen.de Animal Physiological Ecology, Institute for Evolution and Ecology, University of Tübingen, Konrad-Adenauer-Strasse 20, Tübingen 72072, Germany
}

measure of exposure and/or of toxic effect [3]. Biomarker responses, such as gene expression alterations, increased biotransformation enzyme levels, immune responses, histological impairments etc. can provide an early warning on environmental and ecological effects of chemicals [4].

Heat shock proteins (Hsps), also named as stress proteins, are one of the molecular biomarkers of effect which can be used as indicators for cellular and proteototoxic hazard [5]. Among the various stress response pathways, the heat shock response is one of the major ones [6]. The Hsp70 family of stress proteins is an essential class of highly conserved molecular chaperones which are present in different cell types and cellular compartments [7]. Hsp70s serve multiple roles in the prevention of protein aggregation; they are also involved in nascent protein folding, correct refolding of damaged 
polypeptides and assisting cellular protein translocation [8]. A large number of studies [9-11] have demonstrated that Hsp70 expression is closely linked to a variety of biotic and abiotic stress factors showing a high sensitivity even to minor impacts. For example, Hallare and colleagues [12] recorded an up-regulation of Hsp70 levels in zebrafish (Danio rerio) embryos exposed to contaminated sediments and organic extracts collected along the Laguna Lake, Philippines. Their study also confirmed that developing zebrafish embryos are able to detect chemical stressors in their immediate environment [13-16].

Zebrafish are frequently used organisms in biological as well as in ecotoxicological research. The short and well-characterized embryonic ontogenesis (for details, see e.g. [17]) and the transparency of eggs offer a unique opportunity for developmental observations. The fish embryo test (FET) with the zebrafish is a reliable alternative to existing in vivo ecotoxicity test methods [18] for investigating the adverse effects of aquatic pollutants [19-22]. Compared to other toxicity screening assays, the FET is in most cases more sensitive than the acute toxicity test with adult zebrafish or than certain cell line tests [23].

The current work is part of an extended monitoring project focussing on the Neckar River system in the Tübingen area (Southern Germany). The Neckar River is an excellent model for ecotoxicological investigations, since it is still recovering from a former heavy pollution caused by rapid industrial development in the last five decades. Today, the water quality is considered as 'moderate' according to the European Water Framework Directive [24]; however, there are still several wastewater loaded sections. Consequently, Braunbeck and colleagues [25] reported the genotoxic effects and strong histological impairments in roach (Rutilus rutilus) and gudgeon (Gobio gobio) from the lower Neckar region. Also, sediment extracts from a Neckar River basin creek receiving treated hospital wastewater were found to exhibit strong aromatic hydrocarbon receptor-mediated effects in a rainbow trout liver cell line (RTL-W1) as well as high mutagenicity in the Salmonella microsome assay [26].

The present study investigates embryo- and proteotoxic effects of native Neckar River water and sediment from the Tübingen area collected in different seasons over 2 years. For this end, zebrafish embryo tests combined with an analysis of the stress protein Hsp70 in newly hatched larvae were conducted. Additionally, measurements of physico-chemical parameters were carried out in order to provide basic information about the limnological conditions at the river sections. Our goals are, on the one hand, the evaluation of early developmental responses of zebrafish to native environmental samples at the whole organism level as well as on the cellular level and, on the other hand, the assessment of the ecotoxicological consequences of small-scale time and spatial variation in a model aquatic system.

\section{Results}

\section{Physico-chemical water properties}

The Neckar River revealed good dissolved oxygen conditions and a normal $\mathrm{pH}$ and hardness range at all sampling sites over both seasons and years (Figures 1 and 2). According to the LAWA water classification, nitrite-N values varied between the classes $\mathrm{I}$ and I-II, nitrate-N concentrations were between class III and subclass IIIIV and ammonium-N concentrates lay overall below $0.04 \mathrm{mg} / \mathrm{L}$ (class I) during the four sampling events. Chloride ions were detected between subclass I-II and class II; the highest values occurred generally at the first sampling site (S1; downstream of the sewage treatment plant (STP) lead-in). Extremely high phosphate values (subclass III-IV and class IV) were found in May 2011 at S3 (upstream of the Ammer lead-in) and S4 (TübingenHirschau), while in 2012, the average range was in class II and subclass II-III.

\section{Fish embryo test}

Exposure to Neckar River water and sediment induced numerous effects during zebrafish ontogenesis. In 2011, a significantly higher mortality was detected in embryos exposed to S4 water and sediment compared to the negative control (Figure 3A,B). Only a minor mortality could be observed in the following spring (Figure 3C), while in autumn 2012, all Neckar River samples induced an elevated mortality (Figure 3D). In the first $60 \mathrm{~h}$ of ontogenesis, strong developmental retardations (delay of spontaneous contractions, low pigmentation, underdeveloped circulation system) were noted at S1 (May 2011, May and September 2012), S2 (May and September 2012), S3 (Mai 2011) and S4 (May and September in both years) (Figure 4). According to this, the abovementioned Neckar River samples also led to modified or even to lack of heartbeat of $48 \mathrm{hpf}$ embryos (Figure 5). During further ontogenesis, developmental failures (yolk and pericardial oedema, pigment failure and tail deformation) occurred in embryos exposed to water and sediment collected at S1 (May 2011, May and September 2012), S2 (May and September 2012), S3 (May and September in both years) and S4 (May and September in both years) (Figure 6). Hatching occurred predominantly between 60 and 96 hpf. The main hatching times (50\% of the surviving individuals reached hatching) are shown in Table 1. Generally, negative control embryos showed a mean hatching time between 66 and 72 hpf; furthermore, $100 \%$ of the surviving individuals reached the larval stage at the age of $96 \mathrm{hpf}$. In contrast, hatching 


\begin{tabular}{|c|c|c|c|c|c|c|}
\hline Physicochemical features & & Site 1 & & Site 3 & & Site 4 \\
\hline Year 2011 & May & September & May & September & May & September \\
\hline Air temperature $\left({ }^{\circ} \mathrm{C}\right)$ & 8.9 & 15.3 & 11.7 & 18.7 & 11.6 & 19.9 \\
\hline Water temperature $\left({ }^{\circ} \mathrm{C}\right)$ & 13.5 & 17.2 & 13.3 & 17.9 & 14.4 & 18.2 \\
\hline $\mathrm{O}_{2}(\mathrm{mg} / \mathrm{L})$ & 9.5 & 7.8 & 11.7 & 9.2 & 11.6 & 9.4 \\
\hline $\mathrm{O}_{2}(\%)$ & 96 & 83 & 106 & 99 & 123 & 99 \\
\hline Conductivity $(\mu \mathrm{S})$ & - & 901 & - & 930 & - & 904 \\
\hline $\mathrm{pH}$ & 8.12 & 8.05 & 8.21 & 8.34 & 8.39 & 8.39 \\
\hline Nitrite-N (mg/L) & 0.03 & 0.01 & 0.04 & 0.02 & 0.04 & 0.02 \\
\hline Nitrate-N (mg/L) & 5.6 & 4.2 & 2.1 & 3.3 & 5.3 & 3.0 \\
\hline Ammonium-N (mg/L) & $<0.04$ & $<0.04$ & $<0.04$ & $<0.04$ & $<0.04$ & $<0.04$ \\
\hline Chloride (mg/L) & 88.7 & 58 & 54.81 & 60 & 58.02 & 50 \\
\hline Ortho-Phosphate-P (mg/L) & 0.23 & 0.06 & 0.74 & 0.08 & 1.11 & 0.05 \\
\hline Overall hardness $\left({ }^{\circ} \mathrm{dH}\right)$ & 29 & 26 & 30 & 27 & 30 & 28 \\
\hline Carbonate hardness $\left({ }^{\circ} \mathrm{dH}\right)$ & 17 & 13 & 16 & 14 & 16 & 16 \\
\hline
\end{tabular}

Figure 1 Basic physical and chemical conditions at three sampling sites along the Neckar River in 2011. Water classification was based on the directives of the German Working Group for Water Issues (LAWA): class I (dark blue) - unpolluted to very slightly polluted, class I-II (light blue) slightly polluted, class II (dark green) - moderately polluted, class II-III (light green) - critically polluted, class III (yellow) - heavily polluted, class III-IV (orange) - very heavily polluted and class IV (red) - excessively polluted [27]. In May 2011, conductivity measurements could not be carried out because of equipment failure. Ammonium- $\mathrm{N}$ values are given in a range due to detecting limitations.

success was significantly lower at S1 (May 2011), S2 (May and September 2012), S3 (September 2011, May 2012) and S4 (both years and seasons) (Figure 7). The strongest effects on hatching were induced by S2 samples with a mean hatching time of $93 \mathrm{hpf}$ in May 2012, while in September 2012, only 26\% of the individuals reached the larval stage at the end of the FET.

\section{Hsp70 analysis}

Neckar River water and sediment from S1 collected in May 2011 led to changes in Hsp70 level of newly hatched zebrafish larvae when compared to the negative control (Figure 8A). Autumn samples from the same year, however, did not reveal any proteotoxic effects (Figure 8B). In the following spring, $\mathrm{S} 1$ embryos showed a significantly lower Hsp70 level, while S3 samples led to a stress protein induction compared to the negative control (Figure 8C). S2 embryos of the above-mentioned sampling event did not manage to reach the larval stage; thus, heat shock protein measurements could not be carried out. In contrast, S2 samples from autumn 2012 led to a significantly reduced Hsp70 level in comparison to the negative control (Figure $8 \mathrm{D}$ ).

\section{Discussion}

The present work reports spatial and temporal variations of embryo- and proteotoxic effects during the early development of zebrafish exposed to native Neckar River samples. A large number of studies revealed that hydrological events such as high/low water discharges and sediment re-mobilization through heavy rainfall could lead to short-term toxicity changes and to a seasonal

\begin{tabular}{|l|c|c|c|c|c|c|c|c|}
\hline Physicochemical features & \multicolumn{2}{|c|}{ Site 1 } & \multicolumn{2}{c|}{ Site 2 } & \multicolumn{2}{c|}{ Site 3 } & \multicolumn{2}{c|}{ Site 4 } \\
\hline \multicolumn{1}{|c|}{ Year 2012 } & May & Sept. & May & Sept. & May & Sept. & May & Sept. \\
\hline Air temperature $\left({ }^{\circ} \mathrm{C}\right)$ & 13.3 & 17.4 & 15.3 & 21.0 & 24.1 & 27.6 & 25.1 & 22.7 \\
\hline Water temperature $\left({ }^{\circ} \mathrm{C}\right)$ & 14.5 & 15.9 & 15.1 & 15.9 & 16.2 & 15.7 & 16.0 & 16.1 \\
\hline $\mathrm{O}_{2}(\mathrm{mg} / \mathrm{L})$ & 9.7 & 9.56 & 9.55 & 9.21 & 11.82 & 10.6 & 11.8 & 13.24 \\
\hline $\mathrm{O}_{2}(\%)$ & 99.1 & 101.2 & 97.3 & 95.1 & 112 & 107.2 & 108 & 134 \\
\hline Conductivity $(\mu \mathrm{S})$ & 924 & 1035 & 901 & 953 & 889 & 938 & 849 & 937 \\
\hline $\mathrm{pH}$ & 7.74 & 8.25 & 8.12 & 8.05 & 8.28 & 8.08 & 8.48 & 8.22 \\
\hline Nitrite-N $(\mathrm{mg} / \mathrm{L})$ & 0.03 & 0.01 & 0.03 & 0.02 & 0.04 & 0.02 & 0.04 & 0.01 \\
\hline Nitrate-N $(\mathrm{mg} / \mathrm{L})$ & 5.0 & 5.2 & 3.4 & 3.6 & 3.8 & 3.4 & 3.4 & 3.8 \\
\hline Ammonium-N $(\mathrm{mg} / \mathrm{L})$ & $<0.04$ & $<0.04$ & $<0.04$ & $<0.04$ & $<0.04$ & $<0.04$ & $<0.04$ & $<0.04$ \\
\hline Chloride $(\mathrm{mg} / \mathrm{L})$ & 58 & 70 & 51 & 55 & 50 & 55 & 46 & 55 \\
\hline Ortho-Phosphate-P $(\mathrm{mg} / \mathrm{L})$ & 0.20 & 0.16 & 0.16 & 0.10 & 0.16 & 0.10 & 0.16 & 0.10 \\
\hline Overall hardness $\left({ }^{\circ} \mathrm{dH}\right)$ & 26 & 29 & 26 & 28 & 28 & 28 & 27 & 27 \\
\hline Carbonate hardness $\left({ }^{\circ} \mathrm{dH}\right)$ & 15 & 14 & 16 & 16 & 17 & 15 & 16 & 15 \\
\hline
\end{tabular}

Figure 2 Basic physical and chemical conditions at four sampling sites along the Neckar River in 2012. Water classification was based on the directives of the German Working Group for Water Issues (LAWA): class I (dark blue) - unpolluted to very slightly polluted, class I-II (light blue) slightly polluted, class II (dark green) - moderately polluted, class II-III (light green) - critically polluted, class III (yellow) - heavily polluted, class III-IV (orange) - very heavily polluted and class IV (red) - excessively polluted [27]. Ammonium-N values are given in a range because of detecting limitations. 

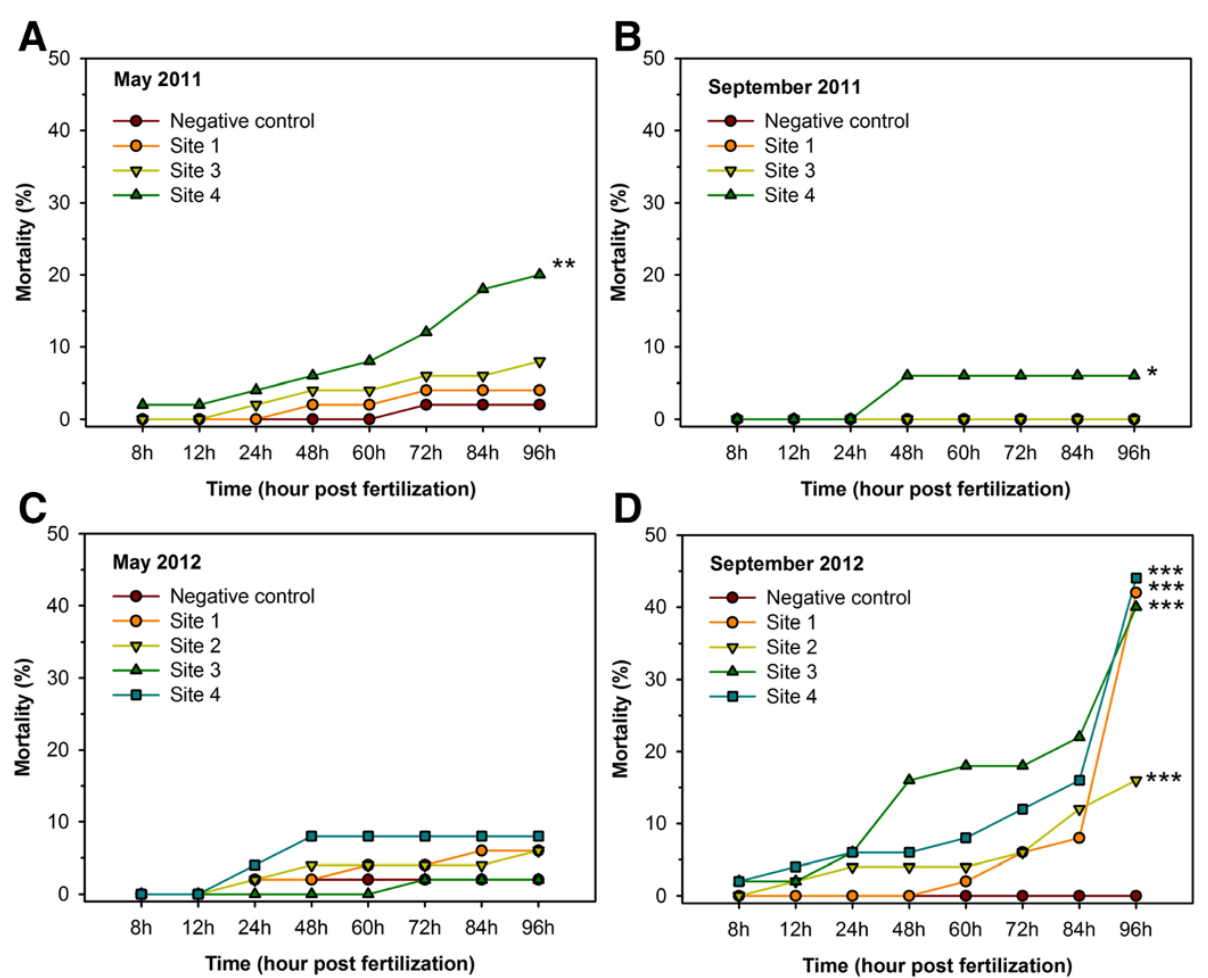

Figure 3 Mortality during the fish embryo test. Zebrafish embryos were exposed to the Neckar River samples collected in May 2011 (A), September 2011 (B), May 2012 (C) and September 2012 (D). Asterisks show significant differences $\left({ }^{*} p<0.05,{ }^{* *} p<0.01,{ }^{* * *} p<0.001, a=0.05\right)$ between sampling site exposure and negative control. Combined data of two replicates was assessed by the Cox proportional hazards survival model.

burden [28-32]. There were strong water level alterations at the Neckar River and tributaries during the 2 years of investigation. An average gauge was recorded in the late spring 2011, while autumn rains led to an elevated water level. The Neckar River revealed in the following May a normal water level, while in September 2012, heavy rainfall events occurred again (stronger than in 2011).

S1 exposure led to developmental deficits during the zebrafish ontogenesis. Since the site mentioned was situated downstream of the Tübingen STP, a contaminant input through the municipal wastewater discharge has to be considered. As a further consequence of the STP presence [33], increased chloride and nitrate values could be detected at S1. In 2011, a slower development and higher number of malformations were observed in spring compared to autumn. There are several studies reporting a lower contaminant level in the rainy period [32,34-36]; thus, increased dilution of discharged contaminants may be a possible interpretation for lower embryotoxicity by autumn samples. Unexpectedly, in September 2012, an extraordinary high mortality was observed at all sites, especially after $84 \mathrm{hpf}$. Since heavy rainfalls occurred just shortly before this sampling event, there is a possibility of toxic input through untreated effluents of the STP storm water overflow and through urban runoff as well [37]. The noticeable mortality increase after hatching can be elucidated through the barrier function of the embryonic chorion, which has a structure pierced by pore canals. Polymers and higher molecular weight surfactants, for instance, are suspected to be blocked by the chorion [38].

Native samples from S2 induced numerous negative effects during zebrafish ontogenesis. The close proximity of the Ammer River lead-in may explain the extremely slow development and malformations of the embryos; thus as mentioned before, a series of organic contaminants were reported in this Neckar River tributary. Liu and colleagues highlighted that high flow events by the Ammer River may result in the redistribution of sediments [39], which may clarify why autumn S2 samples induced stronger teratogenic impairments compared to the spring ones. A similar process was reported at the lower Neckar area as well: there were persistent organic compounds (polychlorinated dibenzo-p-dioxins, dibenzofurans, polychlorinated biphenyls, polycyclic aromatic hydrocarbons) detected in settling particulate matter (SPM) during a flood event in the Heidelberg region [40]. Hollert and co-workers [41] investigated the cytoand genotoxic potentials of the above-mentioned river samples: SPM taken during the period of flood rise 

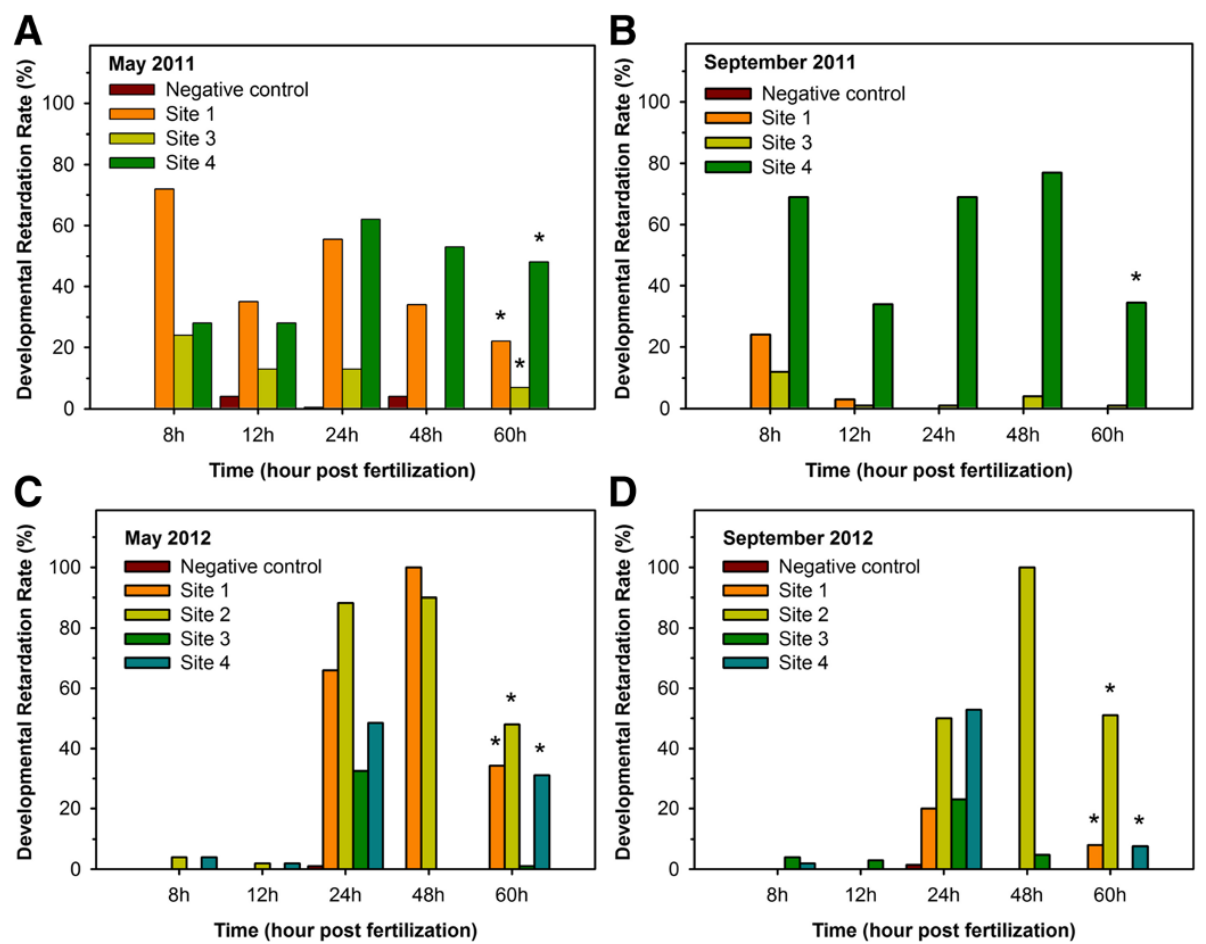

Figure 4 Developmental retardation rate of zebrafish embryos in the first 60 hpf. Fish embryo test with water and sediment from the Neckar River collected in May 2011 (A), September 2011 (B), May 2012 (C) and September 2012 (D). Developmental retardation rate is given as percentage of the observed retardations divided by the total possible ones at appropriate time points. Vertical bars show the mean of two replicates. Asterisks show significant differences ( ${ }^{*} p<a$ when adjusted according to Holm-Bonferroni's method) between sampling site exposure and negative control at $60 \mathrm{hpf}$ assessed by Fisher's exact test.

showed the highest cytotoxic activities in the neutral red retention assay, while the Ames test delivered no evidence for any genotoxic activity. Therefore, as a consequence of flood events, runoff and remobilized sediments may cause an increase of ecotoxicologically relevant effects from contaminant reservoirs [40].

S3 was located $800 \mathrm{~m}$ upstream of the Ammer River, with the Steinlach creek as the only lead-in. Our study confirmed the fact of Steinlach having a good water quality, since during the most sampling events only minor developmental abnormalities could be observed by the FET. Interestingly, in 2012, S3 embryos showed an increased heart rate compared to the negative control. This phenomenon may be a sign for an elevated metabolism due to toxicant elimination, since heartbeat frequency in fish can be strongly affected by the metabolic rate [42]. In autumn 2012, an elevated mortality was detected at the whole investigated Neckar section, including S3. Here, the potential pollution source is unclear as of jet; however, substance drifting from S4 due to the increased water level may be a reasonable possibility. As an evidence, in spring 2011, extraordinarily high phosphate concentrations were detected at S3, while S4 showed an even higher value.

S4 was considered as the most nature-close sampling site, since it was located outside the city area with no discharges in close proximity; however, an agricultural activity was still present. Surprisingly, this site caused the highest mortality and heartbeat reduction during all four sampling events. Numerous developmental retardations and failures and lower hatching rates were recorded as well. One possible contaminant source could be the agricultural runoff, which may explain the strong embryotoxic effects and the elevated nitrate and phosphate levels in spring. Abandoned discharges and past substance burden would deliver further explanations; unfortunately, there is no information available about these.

Parallel to the present study, Hollert and colleagues [43] observed a broad range of embryotoxic effects of native water and sediments from the Heidelberg Neckar region through the zebrafish sediment contact assay. Nevertheless, they also proved the suitability of the zebrafish embryo test for the analysis of complex environmental samples including the whole sediments. According to their FET results, sediment extracts from the above-mentioned area exhibited dioxin-like potentials when tested with the 7-ethoxyresorufin-O-deethylase (EROD) assay on a permanent cell line [44].

The present study is the first work reporting proteotoxic effects in the Neckar River. The results of the 

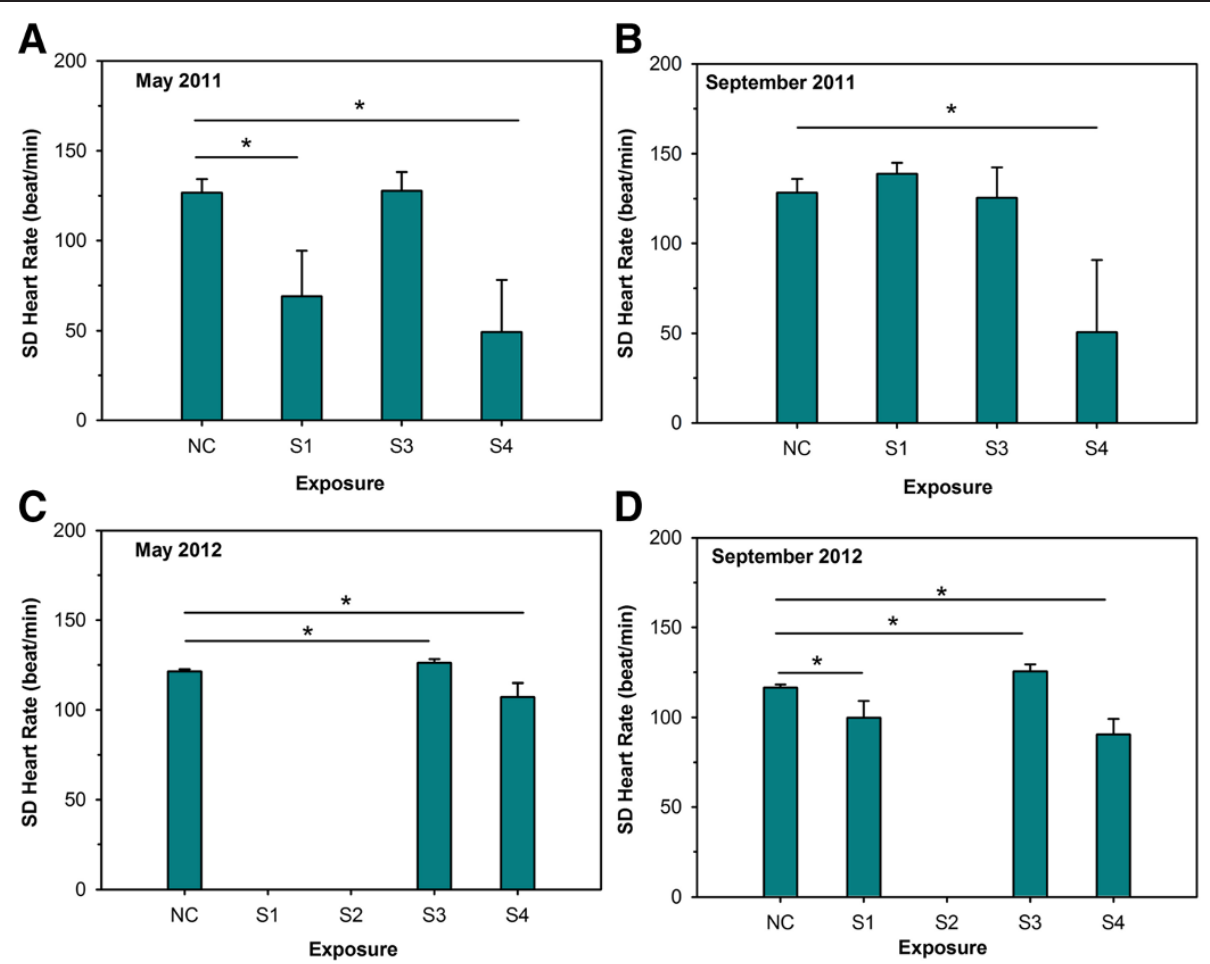

Figure 5 Heart rate of zebrafish embryos at $\mathbf{4 8} \mathbf{~ h p f ~ d u r i n g ~ t h e ~ f i s h ~ e m b r y o ~ t e s t . ~ E m b r y o s ~ w e r e ~ e x p o s e d ~ t o ~ N e c k a r ~ R i v e r ~ s a m p l e s ~ f r o m ~ M a y ~}$ 2011 (A), September 2011 (B), May 2012 (C) and September 2012 (D). Vertical bars show standard deviations. Asterisks indicate significant differences $\left({ }^{*} p<0.05, a=0.05\right)$ between river sample treatment and negative control assessed by Tukey-Kramer test. Results of two independent replicates are shown.

Hsp70 quantification in newly hatched zebrafish larvae provided additional information about the sublethal effects of environmental samples on the molecular level. There was a decreased heat shock protein level detected at S1 (May 2011 and 2012) and S2 (September 2012), while S3 (May 2012) exposure led to a stress protein induction when compared to the negative control. Elevated stress protein values indicate proteotoxic conditions, since heat shock proteins play an essential role in protein integrity maintenance and prevent aggregation [45]. Decreasing cellular heat shock protein amounts, however, can be interpreted as signs of a very intense stress response [46] in which case the organism is heading towards physiological breakdown and destruction. For this reason, the molecular biomarker Hsp70 should be combined with additional methods such as histopathology [47], biotransformation enzyme activity measurements $[48,49]$ etc. in order to provide reliable information on toxic effects in different organisms. For example, in the frame of an extended monitoring project at Lake Constance tributaries, Triebskorn and colleagues integrated Hsp70 measurements in a battery of chemical and biological methods also including the fish embryo test [50]. The combination of the various techniques offered a way to establish plausible connections between the presence of micropollutants and the respective effects on fish health.

\section{Conclusions}

The current work is a field survey not only of local but also of general relevance. The Neckar River proved to be an excellent model for ecotoxicological investigations due to the impact of variable anthropogenic pollutant sources. Toxicity alterations along the investigated river section could be connected to the potential pollution sources, sampling seasons and raining events. Our study highlighted that a seasonal burden has to be taken into account during environmental monitoring. The in vivo assays applied in the present work focussed on diverse toxic aspects on different organization levels of zebrafish; thus, the fish embryo test revealed developmental toxicity on the organismal level, while the analysis of the stress protein Hsp70 assessed proteotoxicity on the subcellular level. The basic physico-chemical measurements contributed only in a limited way to the interpretation of the FET results. Therefore, little is known about the actual toxic loads of the Neckar River in the Tübingen area. The authors also want to highlight that the present work focussed only on the effects of a short-term exposure in a laboratory model organism to environmental 

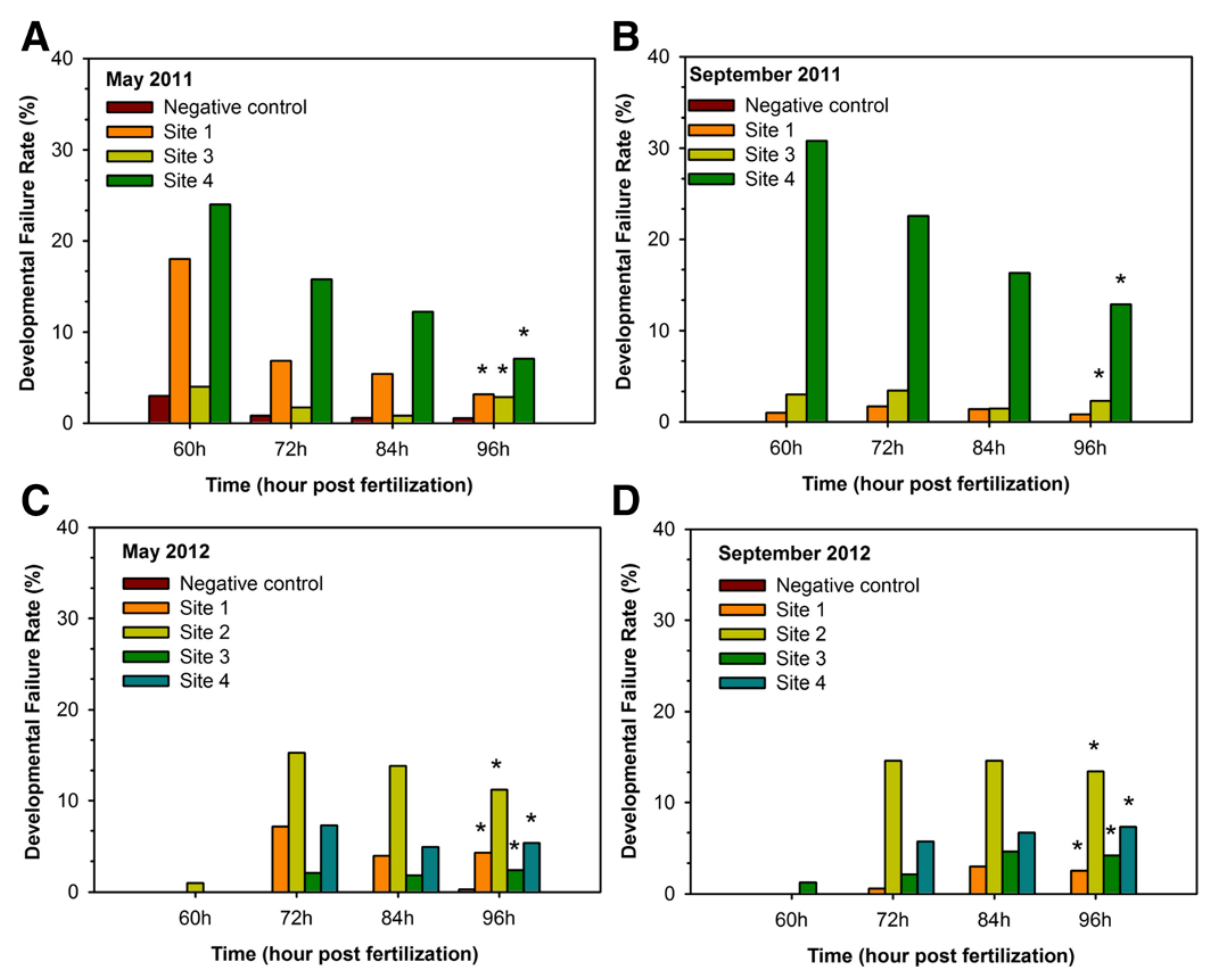

Figure 6 Developmental failure rate between 60 and 96 hpf during the fish embryo test. Zebrafish embryos were exposed to water and sediment collected at the Neckar River in May 2011 (A), September 2011 (B), May 2012 (C) and September 2012 (D). Developmental failure rate is given as percentage of the observed failures divided by the total possible ones at appropriate time points. Vertical bars show the mean of two replicates. Asterisks indicate significant differences ( ${ }^{*} p<a$ when adjusted according to Holm-Bonferroni's method) between sampling site exposure and negative control at $96 \mathrm{hpf}$ assessed by Fisher's exact test.

samples; the physiological responses of feral animals, long-term consequences and cause-effect relationships (biological data combined with chemical analysis results) will be discussed in the frame of further publications.

\section{Methods}

\section{Ethics statement}

Zebrafish were maintained according to the European Union Animals Ethics Directive [51]. Fish embryo tests were carried out on the non-protected embryonal and larval stages. Experiments with extended exposure times $(168 \mathrm{~h})$ were approved by the Animal Ethics Committee of the Regional Council Tübingen (permission number: ZP 2/11). Zebrafish embryos and larvae were sacrificed through an anaesthetic overdose of $40 \mathrm{mg} / \mathrm{mL}$ benzocaine solution.

\section{Sampling sites}

For the current project, four sites were selected along the Neckar River in the Tübingen region (Figure 9). S1 was located $150 \mathrm{~m}$ downstream of the local STP discharger $\left(9^{\circ} 6^{\prime} 41.08^{\prime \prime} \mathrm{N}, 48^{\circ} 32^{\prime} 16.44^{\prime \prime} \mathrm{E}\right)$. The Tübingen STP is a conventional municipal treatment plant with no additional upgrades and a daily load between 40,000 and $50,000 \mathrm{~m}^{3}$ [52]. At S1, the Neckar River is about $20 \mathrm{~m}$ wide, $2 \mathrm{~m}$ deep with a flow velocity between 0.3 and 0.5 $\mathrm{m} / \mathrm{s}$ (depending on raining events). The second site (S2) was situated $1 \mathrm{~km}$ upstream of the local STP and $100 \mathrm{~m}$

Table 1 Mean hatching times during the zebrafish embryo test

\begin{tabular}{llllll}
\hline Mean hatching time & Negative control & Site 1 & Site 2 & Site $\mathbf{3}$ & Site $\mathbf{4}$ \\
\hline May 2011 & $66 \mathrm{hpf}$ & $69 \mathrm{hpf}$ & n.a. & $58 \mathrm{hpf}$ & $\mathbf{7 9} \mathrm{hpf}$ \\
September 2011 & $67 \mathrm{hpf}$ & $63 \mathrm{hpf}$ & n.a. & $81 \mathrm{hpf}$ \\
May 2012 & $72 \mathrm{hpf}$ & $81 \mathrm{hpf}$ & $93 \mathrm{hpf}$ & $85 \mathrm{hpf}$ \\
September 2012 & $68 \mathrm{hpf}$ & $59 \mathrm{hpf}$ & $26 \%$ at $96 \mathrm{hpf}$ & $63 \mathrm{hpf}$ & $68 \mathrm{hpf}$ \\
\hline
\end{tabular}

Mean hatching time is defined as the time point when $50 \%$ of the surviving fish embryos hatched. Mean hatching times were calculated in SigmaPlot 10.0 by graphic analysis of the combined hatching curves of two independent replicates. n.a. not available. 

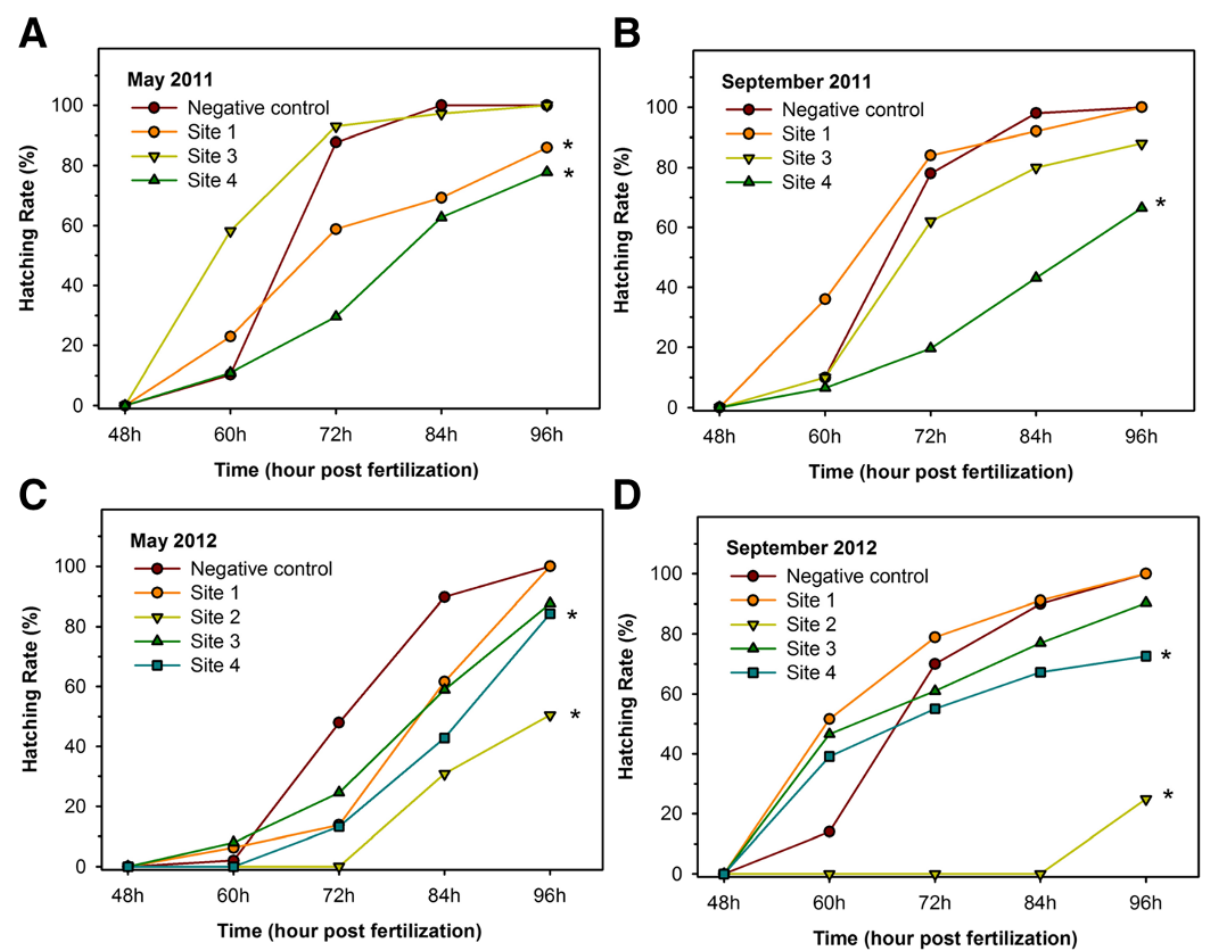

Figure 7 Hatching rate of zebrafish embryos during the fish embryo test. Embryos were exposed to water and sediment samples of the Neckar River from May 2011 (A), September 2011 (B), May 2012 (C) and September 2012 (D). Hatching rate shows the percentage of hatched larvae in relation to the surviving individuals. The combined data of two replicates is shown. Asterisks indicate significant differences $\left({ }^{*} p<a\right.$ when adjusted according to Holm-Bonferroni's method) between sampling site exposure and negative control at 96 hpf assessed by Fisher's exact test.

downstream of the influent of the Ammer River $\left(9^{\circ} 5^{\prime}\right.$ $\left.19.97^{\prime \prime} \mathrm{N}, 48^{\circ} 31^{\prime} 34.32^{\prime \prime} \mathrm{E}\right)$. It reveals a flow velocity of 0.2 $\mathrm{m} / \mathrm{s}$, a width of $36 \mathrm{~m}$ and a depth of $2 \mathrm{~m}$. In the past few years, there were organic contaminants detected in the Ammer River: polycyclic aromatic hydrocarbons were found in the sediment with a concentration ranging from 112 to $22.900 \mathrm{ng} / \mathrm{g}$ dry weight [39], and an accumulation of polychlorinated biphenyls in the tissues of brown trouts was observed as well [53]. On this account, a third site (S3) was assigned located $800 \mathrm{~m}$ upstream of the Ammer lead in $\left(9^{\circ} 5^{\prime} 1.28^{\prime \prime} \mathrm{N}, 48^{\circ} 31^{\prime} 23.05^{\prime \prime} \mathrm{E}\right)$ with a flow velocity of 0.3 to $0.5 \mathrm{~m} / \mathrm{s}$, a width of $40 \mathrm{~m}$ and an overall depth of approximately $1 \mathrm{~m}$. The Steinlach River leads into the Neckar River about 300 m upstream of S3, its water quality is considered good and showed recently a strong improvement [54] contrary to the Ammer. The fourth sampling site (S4) was located about $4.2 \mathrm{~km}$ upstream, outside the city area $\left(9^{\circ} 1^{\prime} 8.76^{\prime \prime} \mathrm{N}, 48^{\circ} 29^{\prime} 59.24^{\prime \prime}\right.$ E) where no STP effluents are registered in close proximity. The flow velocity of the Neckar River at this site ranges between 0.1 and $0.3 \mathrm{~m} / \mathrm{s}$, its overall width $30 \mathrm{~m}$ and depth $1.2 \mathrm{~m}$.

\section{Sampling events}

Monitoring was conducted over 2 years: during 2011 and 2012. Sampling was performed two times per year: in May and September. At this point, the authors want to highlight that S2 was subsequently added to the study in 2012; thus in 2011, only S1, S3 and S4 were investigated.

For the fish embryo test and Hsp70 analysis, $2 \mathrm{~L}$ of water and $200 \mathrm{~g}$ of fine-grained sediment from the upper aerobic layers were taken near the riverbank in sterile glass flasks (Schott Duran, Mainz, Germany) at each sampling site. Samples were transported in a cooling box at approximately $4^{\circ} \mathrm{C}$ to the laboratory facility of the Animal Physiological Ecology Group of the University of Tübingen. Water samples were divided into 0.5 - $\mathrm{L}$ glass flasks (Schott Duran) while the sediment was distributed into 50-g packages wrapped in aluminium foil (Roth, Karlsruhe, Germany). Neckar River water and sediment were frozen immediately and stored at $-20^{\circ} \mathrm{C}$ until further use.

\section{Physico-chemical water parameter}

On the day of sampling, air and water temperatures were measured close to the riverbank with a multithermometer (Voltcraft, Hirschau, Germany) at all field sites. Oxygen, $\mathrm{pH}$ and conductivity levels were captured through sensors (Oxi 340-A/SET, pH 330/SET TRW, LF 330/SET, WTW, Weilheim, Germany) on the same spots where water and sediment were obtained for the biotests. Additionally, $1 \mathrm{~L}$ of water was collected in a sterile 

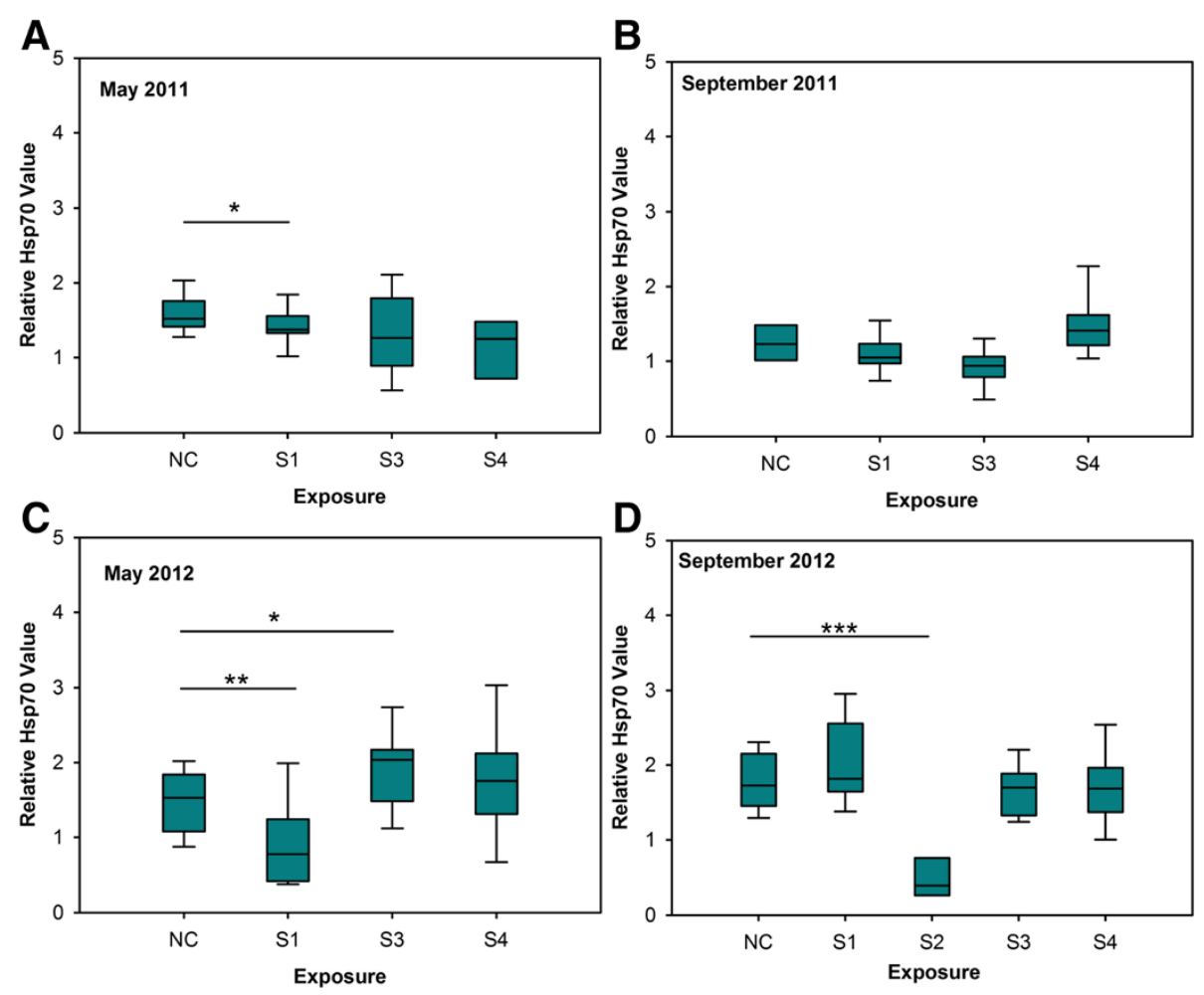

Figure 8 Relative Hsp70 value of $\mathbf{1 6 8}$ hpf zebrafish larvae. Larvae were exposed to Neckar River water and sediment collected in May 2011 (A), September 2011 (B), May 2012 (C) and September 2012 (D). Relative Hsp70 value is given in relation to the mean of two internal standards. Box plots represent medians and 5th/95th percentiles. Where $n<10$, no plot whiskers are shown. Asterisks indicate significant $\left(^{*} p<0.05\right.$, ${ }^{* *} p<$ $\left.0.01,{ }^{* *} p<0.001, a=0.05\right)$ differences between river sample treatment and negative control assessed by Steel-Dwass (nonparametric) or TukeyKramer (parametric) test.

glass flask (Schott Duran) at all Neckar River sites and transported to the laboratory facility of the Animal Physiological Ecology Group of the Tübingen University in a cooling box $\left(4^{\circ} \mathrm{C}\right)$. Chloride, nitrate, nitrite, ammonium, phosphate (test kits from Macherey-Nagel, Düren, Germany), carbonate and overall hardness (test kits from Merck, Darmstadt, Germany) levels of the water samples were determined immediately. Classification of the water quality was carried out according to the directives of the German Working Group for Water Issues (LAWA) including seven assessment groups: class I - unpolluted to very slightly polluted, class I-II - slightly polluted, class II - moderately polluted, class II-III - critically polluted, class III - heavily polluted, class III-IV - very heavily polluted and class IV - excessively polluted [27].

\section{Maintenance and breeding of zebrafish}

The Animal Physiological Ecology Group of the Tübingen University reared several stocks of zebrafish based on the West Aquarium strain. Fish were kept at $26^{\circ} \mathrm{C} \pm$ $1^{\circ} \mathrm{C}$ in 100 - to $200-\mathrm{L}$ tanks in filtered (AE-2 L water filter equipped with an ABL-0240-29 activated carbon filter $(0.3 \mu \mathrm{m})$, Reiser, Seligenstadt, Germany) tap water under semi-static conditions, with $30 \%$ of water volume being exchanged every 14 days. The room was lightisolated, and an artificial dark-light cycle of 12:12 h was maintained. Animals were fed three times daily with dry flake food (TetraMin ${ }^{\mathrm{Tm}}$, Tetra, Melle, Germany) and additionally with freshly hatched Artemia larvae (Sanders, Mt. Green, MT, USA) on the day before spawning. For egg production, a stainless steel grid box with a mesh size of $1.5 \mathrm{~mm}$ in a plastic basin was positioned at the bottom of the aquaria in the evening before spawning. The grid allowed the passage of eggs into the separate spawning tray, thus preventing predation by adult zebrafish, while green plastic wire material adjusted to the boxes served as spawning stimulus. Spawning took place in the early morning period after the onset of light. Eggs were collected 30 to $60 \mathrm{~min}$ after spawning.

\section{The fish embryo test}

For each sampling event, two independent replicates (two tests at different time points) of the fish embryo test were conducted according to the work of Hallare and colleagues [12]. In the evening before the test onset, five glass Petri dishes (30-mm diameter with cover, Schott Duran) per each field site were saturated with approximately $2.5 \mathrm{~g}$ of the corresponding Neckar River 


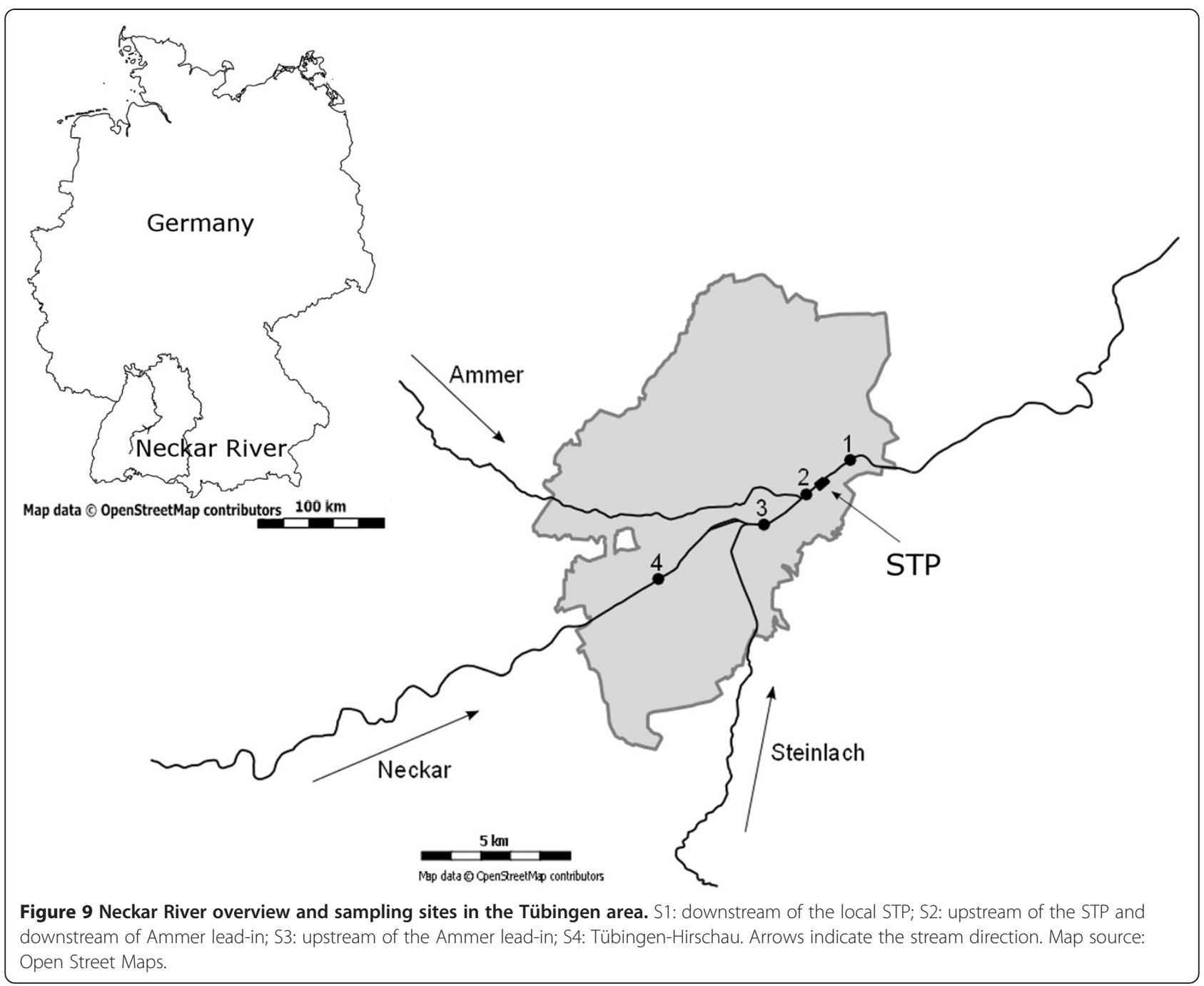

sediment and filled with the appropriate water sample to the top. For negative control, additional five Petri dishes were saturated with reconstituted soft water according to ISO 7346/3 [55]. Test dishes were incubated in a heating cabinet (Aqualytic, Dortmund, Germany) at $26^{\circ} \mathrm{C} \pm 1^{\circ} \mathrm{C}$ overnight.

In the morning of the test onset, saturation medium was replaced with $2.5 \mathrm{~g}$ of the corresponding sediment sample, and Petri dishes were filled with the appropriate Neckar water to the top. There were identical water and sediment batches used for the saturation step and for the actual test. Reconstituted soft water of the negative control was changed as well. Freshly laid eggs (max 60 min post-fertilization) were collected from the aquaria and were immediately distributed into sterile $90-\mathrm{mm}$ diameter glass Petri dishes (Schott Duran) filled with Neckar water samples and ISO water, respectively (one dish per treatment). Thus, exposure circumstances were ensured from the very beginning of the development.
After $2 \mathrm{~h}$ of incubation at $26^{\circ} \mathrm{C}$, five fertilized embryos were transferred subsequently into each test Petri glass from the corresponding pre-exposure dish. Embryos were incubated in a heating cabinet at $26^{\circ} \mathrm{C} \pm 1^{\circ} \mathrm{C}$ for 96 $\mathrm{h}$ at a 12:12-h dark-light cycle. Coagulated embryos were removed daily. If necessary, the amount of evaporated water was substituted from the corresponding sample batch. The development of embryos was observed through a binocular (Stemi 2000-C, Zeiss, Oberkochen, Germany) at several time points $(6,12,24,48,60,72,84$ and $96 \mathrm{~h}$ post-fertilization (hpf)). Mortality was recorded at all observation events. Heartbeat was assessed at the age of $48 \mathrm{hpf}$ : for each embryo, heartbeats were counted for $20 \mathrm{~s}$, and test dishes were evaluated in a random order to avoid temperature effects. Developmental retardation and failures were recorded at relevant time points (Table 2). Retardation and failure rates for each time point were estimated as percentage of the observed retardations or failures divided by the total possible 
Table 2 Endpoints of the fish embryo test with the zebrafish (based on Nagel [22])

\begin{tabular}{|c|c|c|c|c|c|c|c|c|}
\hline \multirow[t]{2}{*}{ Observed endpoints } & \multicolumn{8}{|c|}{ Hours post-fertilization } \\
\hline & 8 & 12 & 24 & 48 & 60 & 72 & 84 & 96 \\
\hline Mortality & · & $\cdot$ & $\cdot$ & $\cdot$ & $\cdot$ & $\cdot$ & $\cdot$ & $\cdot$ \\
\hline Hatching & & & & & $\cdot$ & $\cdot$ & $\cdot$ & $\cdot$ \\
\hline \multicolumn{9}{|l|}{ Slowed ontogenesis/Retardation } \\
\hline Epiboly & · & & & & & & & \\
\hline Gastrulation & & $\cdot$ & & & & & & \\
\hline Exogastrulation & & $\cdot$ & & & & & & \\
\hline Formation of somites & & & $\cdot$ & & & & & \\
\hline Tail detachment & & & $\cdot$ & & & & & \\
\hline Spontaneous movements & & & $\cdot$ & & & & & \\
\hline Development of eyes & & & $\cdot$ & & & & & \\
\hline Number of heartbeats (beats/min) & & & & $\cdot$ & & & & \\
\hline Blood circulation & & & & $\cdot$ & & & & \\
\hline Sacculi/Otolith formation & & & & & $\cdot$ & & & \\
\hline Presence of melanocytes & & & & & $\cdot$ & & & \\
\hline \multicolumn{9}{|l|}{ Developmental failures } \\
\hline Oedema & & & & & $\cdot$ & $\cdot$ & $\cdot$ & $\cdot$ \\
\hline Malformation of head & & & & & $\cdot$ & $\cdot$ & $\cdot$ & $\cdot$ \\
\hline Tail deformation & & & & & & $\cdot$ & $\cdot$ & $\cdot$ \\
\hline Pigmentation failure & & & & & & $\cdot$ & $\cdot$ & $\cdot$ \\
\hline Helical body & & & & & & $\cdot$ & $\cdot$ & $\cdot$ \\
\hline Scoliosis & & & & & & $\cdot$ & $\cdot$ & $\cdot$ \\
\hline
\end{tabular}

ones. The time of hatching was recorded between 60 and $96 \mathrm{hpf}$. Mean hatching times (50\% of the individuals hatched) were estimated as well.

\section{Hsp70 quantification}

For each sampling site, three 90-mm-diameter glass Petri dishes (Schott Duran) were saturated with $12.5 \mathrm{~g}$ of Neckar River sediment and were filled with the corresponding water sample to the top the day before the test onset. Reconstituted soft water according to ISO 7346/3 served as negative control. In the next morning, saturation media was replaced with the same amount of water and sediment from the identical sample batch. In the following step, 50 freshly laid (30 to $60 \mathrm{~min}$ postfertilization) zebrafish eggs were placed into each dish. Embryos were incubated in a heating cabinet for $168 \mathrm{~h}$ by the same conditions as described in the FET. Coagulated embryos were removed daily. The amount of evaporated water was replaced from the corresponding sample batch if necessary. At the end of the exposure, newly hatched larvae were collected by pouring the water carefully from the Petri dish through a cellulose paper filter (5951/2, 185-mm diameter, Schleicher \& Schüll, Dassel, Germany). Eight larvae were pooled into an Eppendorf tube (Eppendorf, Hamburg, Germany) and frozen immediately in liquid nitrogen. Samples were stored at $-20^{\circ} \mathrm{C}$ until further processing.

Hsp70 quantification was carried out based on the work of Hallare and colleagues [20]. Pooled zebrafish larvae were ultrasonically homogenized in $20-\mu \mathrm{L}$ extraction buffer $(80 \mathrm{mM}$ potassium acetate, $4 \mathrm{mM}$ magnesium acetate, $20 \mathrm{mM}$ Hepes $\mathrm{pH} 7.5$ (Sigma Aldrich, Deisenhofen, Germany)) for $5 \mathrm{~s}$ and centrifuged for 12 $\mathrm{min}$ at 20,000 g. The total protein concentration for each supernatant was determined according to the method of Bradford [56]. Supernatants for the actual Hsp70 analysis were diluted 2:1 with $3 \%$ sodium dodecyl sulphate (SDS) in TRIS buffer (pH 7) (Sigma Aldrich) and heated at $96^{\circ} \mathrm{C}$ for $5 \mathrm{~min}$. For each sample, $10 \mu \mathrm{g}$ of total protein per lane were loaded on a minigel SDS page. Two lanes per gel were filled with $4 \mu \mathrm{L}$ of a reference homogenate (standard) made of adult zebrafish in order to ensure comparability. Electrophoresis took place at $80 \mathrm{~V}$ for $15 \mathrm{~min}$ followed by $120 \mathrm{~V}$ for approximately $90 \mathrm{~min}$ at $360 \mathrm{~mA}$. Proteins were transferred to a nitrocellulose membrane (Macherey-Nagel) by semi-dry blotting at 10 $\mathrm{V}$ and $90 \mathrm{~mA} /$ filter for $2 \mathrm{~h}$. After blotting, filters were incubated for $2 \mathrm{~h}$ in a blocking solution (1:1 horse serum (Sigma Aldrich) - Tris-buffered saline (TBS) pH 5.7 (Roth)) at room temperature. Hsp70 bands were marked with a mouse anti-human Hsp70 monoclonal antibody (Dianova, Hamburg, Germany) (diluted 1:5,000 in 1:9 horse serum/TBS) and incubated overnight at room temperature. After rinsing the filter in TBS, a goat antimouse IgG $(\mathrm{H}+\mathrm{L})$ antibody coupled to peroxidase (Dianova) (diluted 1:1,000 in 1:9 horse serum/TBS) was applied. Following $2 \mathrm{~h}$ of incubation, an antibody complex was detected by chloronaphthol (Sigma Aldrich) and 0.015\% hydrogen peroxide (Sigma Aldrich) resolved in Tris buffer $(\mathrm{pH}$ 8.5) containing 6\% methanol. After digitalization of the filters, the grey value intensity of Hsp70 bands was measured by densitometric image analysis (Herolab E.A.S.Y., Wiesloch, Germany). Sample Hsp70 levels were normalized by the mean of the two internal standards (reference homogenate) of the corresponding filter.

\section{Statistical analysis}

Mortality during the whole FET time span was evaluated through Cox proportional hazards analysis, a survival model considering multiple observation events [57] used in clinical, epidemiologic and also in ecotoxicological [58] research. Fisher's exact tests (two-tailed) were carried out with the absolute numbers of developmental retardations at $60 \mathrm{hpf}$, developmental failures at $96 \mathrm{hpf}$ and hatched individuals at 96 hpf. In Fisher's exact test, Neckar River exposure groups and negative control were always compared pairwise. According to this, significance levels were 
adjusted using the Holm-Bonferroni method. For the evaluation of embryonic heartbeat and larval Hsp70 level, data was first tested for normal distribution using the Shapiro-Wilks test; in the following step, variance homogeneity was assessed with the Levene test. Where parameter assumptions were met, differences between exposure groups were determined using an all pairs Tukey-Kramer test. Data with non-normal distributions or inhomogeneous variances were analyzed through the non-parametric SteelDwass method. Statistical analysis was carried out using SAS JMP version 9.0 (SAS Institute $\mathrm{GmbH}$, Böblingen, Germany).

\section{Abbreviations}

FET: fish embryo test; hpf: hours post-fertilization; Hsp: heat shock protein: LAWA: German Working Group for Water Issues (Länderarbeitsgemeinschaft Wasser); NC: negative control; STP: sewage treatment plant; S1: site one (downstream of the Tübingen sewage treatment plant); S2: site two (upstream of the Tübingen sewage treatment plant); S3: site three (upstream of the Ammer lead-in); S4: site four (outside the Tübingen city area).

\section{Competing interests}

The authors declare that they have no competing interests.

\section{Authors' contributions}

The physico-chemical measurements, statistical analysis, FET and Hsp70 assessment of 2012 samples was carried out by KV. The manuscript was mainly drafted by KV. KG conducted the FET and Hsp70 assessment of Neckar River samples collected in 2011 and participated in the sampling events. VS took part in the experimental design, participated in the sampling events and gave advice in the data analysis and manuscript drafting. H-RK and RT supervised the current work, supported the publication of the results and provided technical and financial background for the study. All authors read and approved the final manuscript.

\section{Acknowledgements}

The authors acknowledge the Carl Zeiss Foundation, the Foundation of the Landesnaturschutzverband (LNV) Baden-Württemberg and the Deutsche Forschungsgemeinschaft (DFG) Open Access Publishing Fund of the Tübingen University for their financial support. We also thank the co-workers of the Animal Physiological Ecology Group of the Tübingen University, especially to Andreas Dieterich, Anja Henneberg, Stefanie Krais, Diana Maier, Katharina Peschke, Alexandra Scheil, Simon Schwarz and Paul Thellmann for their technical assistance and help in the field. The authors want to thank the three anonymous reviewers for their constructive critics and useful suggestions.

Received: 20 November 2013 Accepted: 24 January 2014

Published: 1 February 2014

\section{References}

1. Moore MN, Depledge MH, Readman JW, Paul Leonard DR: An integrated biomarker-based strategy for ecotoxicological evaluation of risk in environmental management. Mutat Res/Fundam Mol Mech Mutagen 2004, 552:247-268.

2. de la Torre FR, Salibián A, Ferrari L: Assessment of the pollution impact on biomarkers of effect of a freshwater fish. Chemosphere 2007, 68:1582-1590.

3. Peakall DB: The role of biomarkers in environmental assessment (1). Introduction. Ecotoxicol Environ Saf 1994, 3:157-160.

4. Walker CH: Biochemical biomarkers in ecotoxicology—some recent developments. Sci Total Environ 1995, 171:189-195.

5. Gupta SC, Sharma A, Mishra M, Mishra RK, Chowdhuri DK: Heat shock proteins in toxicology: how close and how far? Life Sci 2010, 86:377-384.

6. Westerheide SD, Morimoto RI: Heat shock response modulators as therapeutic tools for diseases of protein conformation. J Biol Chem 2005, 280:33097-33100
7. Bonomo J, Welsh JP, Manthiram K, Swartz JR: Comparing the functional properties of the Hsp70 chaperones, DnaK and BiP. Biophys Chem 2010, 149:58-66.

8. Frydman J: Folding of newly translated proteins in vivo: the role of molecular chaperones. Annu Rev Biochem 2001, 70:603.

9. Köhler $\mathrm{H}-\mathrm{R}$, Eckwert $\mathrm{H}$, Triebskorn R, Bengtsson G: Interaction between tolerance and $70 \mathrm{kDa}$ stress protein (hsp70) induction in collembolan populations exposed to long-term metal pollution. Appl Soil Ecol 1999, 11:43-52.

10. Scheil V, Zürn A, Köhler H-R, Triebskorn R: Embryo development, stress protein ( $\mathrm{Hsp} 70)$ responses, and histopathology in zebrafish (Danio rerio) following exposure to nickel chloride, chlorpyrifos, and binary mixtures of them. Environ Toxicol 2010, 25:83-93.

11. Hofmann GE: Ecologically relevant variation in induction and function of heat shock proteins in marine organisms. Am Zool 1999, 39:889-900.

12. Hallare AV, Kosmehl T, Schulze T, Hollert H, Köhler HR, Triebskorn R: Assessing contamination levels of Laguna Lake sediments (Philippines) using a contact assay with zebrafish (Danio rerio) embryos. Sci Total Environ 2005, 347:254-271.

13. Kosmehl T, Otte JC, Yang L, Legradi J, Bluhm K, Zinsmeister C, Keiter SH, Reifferscheid G, Manz W, Braunbeck T, Strähle U, Hollert H: A combined DNA-microarray and mechanism-specific toxicity approach with zebrafish embryos to investigate the pollution of river sediments. Reprod Toxicol 2012, 33:245-253.

14. Osterauer R, Köhler H-R: Temperature-dependent effects of the pesticides thiacloprid and diazinon on the embryonic development of zebrafish (Danio rerio). Aquat Toxicol 2008, 86:485-494.

15. Yang L, Ho NY, Alshut R, Legradi J, Weiss C, Reischl M, Mikut R, Liebel U, Müller F, Strähle U: Zebrafish embryos as models for embryotoxic and teratological effects of chemicals. Reprod Toxicol 2009, 28:245-253.

16. Weigt S, Huebler N, Strecker R, Braunbeck T, Broschard TH: Zebrafish (Danio rerio) embryos as a model for testing proteratogens. Toxicology 2011, 281:25-36.

17. Kimmel CB, Ballard WW, Kimmel SR, Ullmann B, Schilling TF: Stages of embryonic development of the zebrafish. Dev Dyn 1995, 203:253-310.

18. Embry MR, Belanger SE, Braunbeck TA, Galay-Burgos M, Halder M, Hinton DE, Léonard MA, Lillicrap A, Norberg-King T, Whale G: The fish embryo toxicity test as an animal alternative method in hazard and risk assessment and scientific research. Aquat Toxicol 2010, 97:79-87.

19. Braunbeck T, Böttcher M, Hollert H, Kosmehl T, Lammer E, Leist E, Rudolf M, Seitz N: Towards an alternative for the acute fish LC50 test in chemical assessment: the fish embryo toxicity test goes multi-species - an update. Altex 2005, 22:87-102.

20. Hallare AV, Köhler HR, Triebskorn R: Developmental toxicity and stress protein responses in zebrafish embryos after exposure to diclofenac and its solvent, DMSO. Chemosphere 2004, 56:659-666.

21. Lammer E, Carr GJ, Wendler K, Rawlings JM, Belanger SE, Braunbeck T: Is the fish embryo toxicity test (FET) with the zebrafish (Danio rerio) a potential alternative for the fish acute toxicity test? Comp Biochem Physiol C 2009, 149:196-209.

22. Nagel R: DarT: The embryo test with the zebrafish Danio rerio-a general model in ecotoxicology and toxicology. ALTEX 2002, 19:38-48.

23. Lange M, Gebauer W, Markl J, Nagel R: Comparison of testing acute toxicity on embryo of zebrafish, Brachydanio rerio and RTG-2 cytotoxicity as possible alternatives to the acute fish test. Chemosphere 1995, 30:2087-2102

24. Haberbosch R, Hoffmann R, Wnuck H: Mittlerer Neckar im Wandel der Zeit. In Vom Wildfluss zur Wasserstraße - Fischfauna und Fischerei im Mittleren Neckar. Edited by Haberbosch R, Hoffmann R, Wnuck H. Suttgart: VFG Service und Verlags GmbH; 2012:1721

25. Braunbeck T, Brauns A, Keiter S, Hollert H, Schwartz P: Fischpopulationen unter Stress - das Beispiel des Unteren Neckars. Umweltwissenschaften und Schadstoff-Forschung 2009, 21:197-211.

26. Brack W, Schirmer K, Erdinger L, Hollert H: Effect-directed analysis of mutagens and ethoxyresorufin-O-deethylase inducers in aquatic sediments. Environ Toxicol Chem 2005, 24:2445-2458.

27. Chemical water quality classification, Working Group of the Federal States on Water Issues (LAWA). http://www.umweltbundesamt.de/ wasser-e/themen/fluesse-und-seen/fluesse/bewertung/chemischegewaesserklassifikation.htm.

28. Camacho-Muñoz D, Martín J, Santos JL, Aparicio I, Alonso E: Occurrence of surfactants in wastewater: hourly and seasonal variations in urban and 
industrial wastewaters from Seville (Southern Spain). Sci Total Environ 2014, 468-469:977-984.

29. Gan W, Guo W, Mo J, He Y, Liu Y, Liu W, Liang Y, Yang X: The occurrence of disinfection by-products in municipal drinking water in China's Pearl River Delta and a multipathway cancer risk assessment. Sci Total Environ 2013, 447:108-115.

30. Hsieh C-Y, Yang L, Kuo W-C, Zen Y-P: Efficiencies of freshwater and estuarine constructed wetlands for phenolic endocrine disruptor removal in Taiwan. Sci Total Environ 2013, 463-464:182-191.

31. Hsu P, Matthäi A, Heise S, Ahlf W: Seasonal variation of sediment toxicity in the Rivers Dommel and Elbe. Environ Pollut 2007, 148:817-823.

32. Moliner-Martínez $Y$, Herraez-Hernandez R, Verdú-Andres J, Campíns-Falcó $P$, Garrido-Palanca C, Molins-Legua C, Seco A: Study of the influence of temperature and precipitations on the levels of BTEX in natural waters. J Hazard Mater 2013, 263(Part 1):131-138.

33. Giri S, Singh AK: Risk assessment, statistical source identification and seasonal fluctuation of dissolved metals in the Subarnarekha River, India. $J$ Hazard Mater, 265:305-314.

34. Katip A, Karaer F, lleri S, Sarmasik S, Aydogan N, Zenginay S: Analysis and assessment of trace elements pollution in sediments of Lake Uluabat, Turkey. J Environ Biol 2012, 33:961-968.

35. Palma P, Alvarenga P, Palma V, Matos C, Fernandes R, Soares A, Barbosa I: Evaluation of surface water quality using an ecotoxicological approach: a case study of the Alqueva Reservoir (Portugal). Environ Sci Pollut Res 2010, 17:703-716.

36. Zhu S, Chen H, Li J: Sources, distribution and potential risks of pharmaceuticals and personal care products in Qingshan Lake basin, Eastern China. Ecotoxicol Environ Saf 2013, 96:154-159.

37. VanLandeghem MM, Meyer MD, Cox SB, Sharma B, Patiño R: Spatial and temporal patterns of surface water quality and ichthyotoxicity in urban and rural river basins in Texas. Water Res 2012, 46:6638-6651.

38. Henn K, Braunbeck T: Dechorionation as a tool to improve the fish embryo toxicity test (FET) with the zebrafish (Danio rerio). Comp Biochem Physiol C 2011, 153:91-98.

39. Liu Y, Beckingham B, Ruegner H, Li Z, Ma L, Schwientek M, Xie H, Zhao J, Grathwohl P: Comparison of sedimentary PAHs in the rivers of Ammer (Germany) and Liangtan (China): differences between early- and newly-industrialized countries. Environ Sci Technol 2013, 47:701-709.

40. Wolz J, Engwall M, Maletz S, Olsman Takner H, van Bavel B, Kammann U, Klempt $M$, Weber R, Braunbeck T, Hollert H: Changes in toxicity and Ah receptor agonist activity of suspended particulate matter during flood events at the rivers Neckar and Rhine - a mass balance approach using in vitro methods and chemical analysis. Environ Sci Pollut Res 2008, 15:536-553.

41. Hollert $H$, Dürr M, Erdinger L, Braunbeck T: Cytotoxicity of settling particulate matter and sediments of the Neckar River (Germany) during a winter flood. Environ Toxicol Chem 2000, 19:528-534.

42. Brown C, Gardner C, Braithwaite VA: Differential stress responses in fish from areas of high- and low-predation pressure. J Comp Physiol B 2005, 175:305-312.

43. Hollert H, Keiter S, König N, Rudolf M, Ulrich M, Braunbeck T: A new sediment contact assay to assess particle-bound pollutants using zebrafish (Danio rerio) embryos. J Soils Sediments 2003, 3:197-207.

44. Hollert H, Dürr M, Olsman H, Halldin K, van Bavel B, Brack W, Tysklind M, Engwall M, Braunbeck T: Biological and chemical determination of dioxinlike compounds in sediments by means of a sediment triad approach in the catchment area of the River Neckar. Ecotoxicology 2002, 11:323-336.

45. Porter CM, Janz DM: Treated municipal sewage discharge affects multiple levels of biological organization in fish. Ecotoxicol Environ Saf 2003, 54:199-206.

46. Eckwert $H$, Alberti G, Kohler H-R: The induction of stress proteins (hsp) in Oniscus asellus (Isopoda) as a molecular marker of multiple heavy metal exposure: I. Principles and toxicological assessment. Ecotoxicology 1997, 6:249-262.

47. Rajeshkumar S, Mini J, Munuswamy N: Effects of heavy metals on antioxidants and expression of HSP70 in different tissues of milk fish (Chanos chanos) of Kaattuppalli Island, Chennai, India. Ecotoxicol Environ Saf 2013, 98:8-18.

48. Mayon N, Bertrand A, Leroy D, Malbrouck C, Mandiki SNM, Silvestre F. Goffart A, Thomé J-P, Kestemont P: Multiscale approach of fish responses to different types of environmental contaminations: a case study. Sci Total Environ 2006, 367:715-731.
49. Weber LP, Diamond SL, Bandiera SM, Janz DM: Expression of HSP70 and CYP1A protein in ovary and liver of juvenile rainbow trout exposed to ß-naphthoflavone. Comp Biochem Physiol C 2002, 131:387-394.

50. Triebskorn R, Blaha L, Engesser B, Güde $H$, Hetzenauer $H$, Henneberg A, Köhler H-R, Krais S, Maier D, Peschke K, Thellmann P, Vogel H-J, Kuch B, Oehlmann J, Rault M, Suchail S, Rey P, Rischter D, Sacher F, Weyhmüller M, Wurm K: SchussenAktiv - Eine Modellstudie zur Effizienz der Reduktion der Gehalte an anthropogenen Spurenstoffen durch Aktivkohle in Kläranlagen. Korrespondenz Wasserwirtschaft 2013, 8:427-437.

51. European Union: Directive 2010/63/EU of the European Parliament and of the Council of 22 September 2010 on the protection of animals used for scientific purposes. Off J Eur Union 2010, 276:33-77.

52. EBT - Entsorgungsbetriebe Tübingen Anerkennung Dienstleistung 2004. http://www.um.baden-wuerttemberg.de/servlet/is/11336/.

53. Wieder Fische mit zu hohem PCB-Wert in der Ammer. http://www. tagblatt.de/Home/nachrichten/kreis-tuebingen/ammerbuch_artikel,-WiederFische-mit-zu-hohem-PCB-Wert-in-der-Ammer-_arid,98441.html.

54. Landesanstalt für Umwelt Messungen und Naturschutz Baden-Württemberg (LUBW): Umweltdaten 2012 Baden-Württemberg. In LUBW Landesanstalt für Umwelt, Messungen und Naturschutz Baden-Württemberg (ed) Referat 21 - Nachhaltigkeit, Ressourcenschonung. Stuttgart: ABT Print und Medien GmbH Weinheim; 2012:83.

55. ISO: Water quality - determination of the acute lethal toxicity of substances to a freshwater fish [Brachydanio rerio Hamilton-Buchanan (Teleostei, Cyprinidae)] ISO 7346/3. 1996. http://www.iso.org/iso/ catalogue_detail.htm?csnumber=14030.

56. Bradford MM: A rapid and sensitive method for the quantitation of microgram quantities of protein utilizing the principle of protein-dye binding. Anal Biochem 1976, 72:248-254.

57. Smith T, Smithh B: Survival analysis using Cox proportional hazards modeling for single and multiple event time data. In SAS Conference Proceedings. Seattle: SAS Users Group International; 2003:245-228. 30 March to 2 April 2003.

58. Newman MC, McCloskey JT: Time-to-event analyses of ecotoxicity data. Ecotoxicology 1996, 5:187-196.

doi:10.1186/2190-4715-26-3

Cite this article as: Vincze et al:: Embryotoxic and proteotoxic effects of water and sediment from the Neckar River (Southern Germany) to zebrafish (Danio rerio) embryos. Environmental Sciences Europe 2014 26:3.

\section{Submit your manuscript to a SpringerOpen ${ }^{\odot}$ journal and benefit from:}

- Convenient online submission

- Rigorous peer review

- Immediate publication on acceptance

- Open access: articles freely available online

- High visibility within the field

- Retaining the copyright to your article

Submit your next manuscript at springeropen.com 